\title{
研究課題別事後評価結果
}

1. 研究課題名

脳の動的時空間計算モデルの構築とその実装

2. 研究代表者名及び主たる研究参加者名（研究機関名・職名は研究参加期間終了時点）

研究代表者 合原 一幸 東京大学大学院新領域創成科学研究科 教授

主たる研究参加者 藤井 宏 京都産業大学工学部 教授

小室 元政 帝京科学大学理工学部 助教授

川上博 徳島大学工学部 教授

奈良 重俊 岡山大学工学部 教授

堀尾 喜彦 東京電機大学工学部 教授

関根 好文 日本大学理工学部 教授

塚田 稔 玉川大学工学部 教授

3. 研究内容及び成果

本研究は、脳における二ューロン集団の興奮パターンのダイナミクスを主題とし、そのカオス性と非同期活 動電位パルス群の時空間情報に特に着目して、脳における非線形時空間ダイナミカル情報処理機構に関する数 理モデルを構築・解析するとともに、その基本モデルをアナログ電子回路、非同期電子回路を用いて実装する 基礎技術を開発したものである。このような研究によって、現在のデジタルコンピュータとは発想の異なる、 新しい脳型情報処理システムの構成理論とその八ードウェア化のための基盤技術の確立に大きく寄与した。

本研究は、3つのサブグループ、すなわち

(1)脳の動的時空間計算モデルの理論研究サブグループ

(2)脳の動的時空間計算モデルの実装研究サブグループ

(3)脳の動的時空間計算モデルの実験研究サブグループにより実施された。

主要な研究成果はサブグループ毎に、以下のようにまとめられる。

\section{1．脳の動的時空間計算モデルの理論研究 :}

同期型カオスニューラルネットワークモデルの時空間ダイナミクスと、動的連想記憶、組み合わせ最適化、 フラクタルコーディングなどの情報処理能力との関係を、数理モデルを構築して理論的に明らかにした。ま た、非同期型カオスニューラルネットワークモデルやパルスプロパゲーションネットワークモデルを用いて、 活動電位パルス群の時空間構造を考慮し、ニューラルネットワークにおける双方向機能的結合によるバインデ イング機構やダイナミカルセルアセンブリーの創発機構、さらには時空間情報コーディング機構などを理論的 に解明した。これに加えて研究成果の応用技術を広く探索するために、カオス暗号、音声力オス、カオス制御 など、カオス工学との関連で多様な応用研究を行なった。また、脳における学習・自己組織化過程や概日リズ ム生成機構の分子システム的理解を視野に入れて、遺伝子・タンパク質ネットワークの時空間ダイナミカルモ デルおよび人工的遺伝子・タンパク質ネットワーク設計理論を提案している。

\section{2. 脳の動的時空間計算モデルの実装研究 :}

脳の動的時空間計算モデルを実装する様々な基礎技術を開発した。まずはじめに、カオス二ユーロコンピュ ータ構築用ICチップセットを、実数值演算が可能なアナログ集積回路により実装した。さらにこのチップセッ トによる大規模カオスニューロコンピュータアーキテクチャを提案するとともに、それに基づいたシステムを 実装して、その有用性を確認した。また、トラーベリングセールスマン問題（TSP）や2 次割り当て問題

(QAP)などの最適化問題を高速に解くカオスニューロシステムを専用 IC とともに開発し、その有効性を示 した。さらに、カオスニューロン IC をフラクタルコーディングネットワークに応用し、フラクタルコーディ ングを実装する技術を確立した。次に、活動電位パルスの時空間構造により情報処理を行う二ューロンモデル を提案し、これを連続時間アナログ回路で集積回路化した。一方、フローティングゲートMOSFET を用いた 特性可変非線形抵抗回路を提案し、その応用回路として電圧制御発振回路や力オス発生回路を集積回路化し た。 


\section{3. 脳の動的時空間計算モデルの実験研究 :}

脳の動的時空間計算モデルの理論解析から示唆される情報コーディングや情報処理メカニズムを実験的に検 証するためのいくつかのデータ解析手法を提案するとともに、光計測法などを用いた生理実験およびデー夕解 析を行なった。特に、時系列刺激としでゆらぎ”のないリミットサイクル刺激である周期的時系列刺激、“ゆ らぎ"のあるマルコフ連鎖時系列刺激、およびカオス時系列刺激の LTP／LTD 誘起の関係を比較することによ り、海馬 CA1 においてカオス時系列刺激の系列相関特性に依存した LTP を実験的に観測した。

以上を要するに、脳の動的時空間計算に関する理論的、実装的、および実験的研究により、脳のアナログカ オス性と非同期性に着目した新しい発想に基づく脳型時空間情報処理システムの構成理論とその八ードウェア 化のための基盤技術を開拓するとともに、関連する脳科学、非線形科学、およびゲノム科学についての成果が 得られた。これらの内容は主要研究分野である脳科学のみならず、カオス工学、ゲノム科学等多岐にわたって いる。

4. 事後評価結果

4-1. 外部発表(論文、口頭発表等)、特許、研究を通じての新たな知見の取得等の研究成果の状況

本研究グループは、脳の情報処理にかかわるカオスダイナミックスに注目し、カオスが脳において重要な役 割をはたしているという立場から、カオスの数理理論の構築、その動的な連想記憶への応用、生物システムの 神経系におけるカオスの研究、カオスダイナミックスを利用した情報処理最適化方式の提案、さらに八ードウ エアによるカオスの実装とその神経回路計算への応用など、きわめて幅広い研究を行った。研究は精力的で、 多くの課題で見るべき成果を挙げている。

学術論文として発表したものは、国際学術誌において 49 編、国内誌 22 編、計 71 編にのぼり、この中に はPhysical Review Letters, Neural Computation, IEEE Transactions などの一流誌に載つた論文も多 い。招待講演も多く、国内外での学会発表は 256 件を数える。特許は国内 7 件、海外 2 件である。

研究成果は、理論にかかわるものと、カオスニューラルネットワークの工学的実装にかかわるものとに大別 される。さらに、理論的な研究はカオスの基礎とその応用可能性を広げた研究および実際の脳におけるカオス を観測し、そこから脳の仕組みを解明する計算論的神経科学にかかわるものとに大別されよう。それぞれにお いて、見るべき成果が多数挙がっているが、そのいくつかの例を述べよう。

理論モデルでは実数計算にかかわる時空間計算理論を深めたこと、その応用としての組み合わせ最適化問題 に対する新解法の提唱、カオス暗号の発明、動的連想記憶モデルの解析が特筆されよう。これらはいずれも一 流の学会誌に発表され、国際的に高い評価を受けている。

これらを情報工学として実用化するには、並列計算を非同期で行う計算装置の確立が必要である。本研究で は、一万二ューロン、一億シナプスを実装するカオス二ューロチップの設計に成功しており、これに関する特 許も申請済みである。また、脳科学にかかわる成果としては、情報の時空間符号化に関して、発火率と同期時 間コーディングの関係を明らかにした成果が高く評価される。

問題点を挙げれば、生理学実験にかかわるサブグループとの連携が今ひとつ緊密ではなかったことである。 また本グループの成果がこれまでの情報工学のパラダイムを破り真に有用であることを実証するのは、これか らの課題といえる。

$4-2$. 成果の戦略目標・科学技術への貢献

本研究はカ才ス工学を確立し、その理論的な基礎のみではなくて、それが如何に実用問題に応用できるかを 具体的に明らかにしたのみならず、カオスを含む時空間のダイナミックスが脳の解明にとつてきわめて有用で あることを具体的なモデルと結びつけて明らかにした。さらに、カオスチップの設計と実装は、世界の最先端 を行くもので、非同期並列情報処理機構の技術に新しい局面を開き、今後の情報技術への貢献が大きいものと 期待できる。

4-3．その他の特記事項（受賞歴など）

本研究は、評価の定まっていなかったカオス工学の有用性を明らかにしたもので、報道関係による広報も多 数に上った。2 件の論文賞およびゴールドメダルの受賞、さらに、多くの人材がここから輩出していることも 特筆に価しよう。 
This page updated on September 12, 2003

Copyright(C)2003 Japan Science and Technology_Corporation 